\title{
Performance Evaluation of Various Solar Photovoltaic Module Technologies under Tropical Climate Conditions at Melaka, Malaysia
}

\author{
Hayder Salah Mohammed, Chin Kim Gan and Kyairul Azmi Baharin \\ Energy and Power Systems Research Group-CeRIA, Faculty of Electrical Engineering, \\ Universiti Teknikal Malaysia Melaka, Hang Tuah Jaya, 76100 Durian Tunggal, Melaka, Malaysia
}

\begin{abstract}
The system performance of a grid-connected solar photovoltaic system is one of the most important parameters to monitor the health of the system. This study aims to evaluate the performance of three (3) PV module technologies, namely Thin-Film (TF), Heterojunction with Intrinsic Thin layer (HIT) and monocrystalline which are installed at Universiti Teknikal Malaysia Melaka (UTeM) under Malaysia tropical climate conditions. Actual annual solar resources and PV system's energy output were recorded for two (2) consecutive years, i.e., 2014-2015 using the weather station and solar monitoring system installed in the laboratory. The annual average final yield of the PV systems ranged from $1452-1579.5 \mathrm{kWh} / \mathrm{kWp} / \mathrm{year}$. The average annual performance ratio of the 3 PV systems ranged from $80-91.4 \%$ while the average annual capacity factor of the 3 PV systems ranged from $16.5-18 \%$. The average annual system losses of the 3 PV systems ranged from 154.46-302.15 $\mathrm{kWh} / \mathrm{kWp}$ while the average annual array capture losses of the $3 \mathrm{PV}$ systems ranged from $-6.36-59.71$ $\mathrm{kWh} / \mathrm{kWp}$. Outdoor assessment shows that the thin-film PV system had the highest performance ratio and capacity factor. Furthermore, the thin-film PV system produced the lowest system losses and array capture losses, compared to HIT and monocrystalline PV systems.
\end{abstract}

Key words: Photovoltaic (PV), Performance Ratio (PR), system losses, array capture losses, grid-connected, monocrystalline

\section{INTRODUCTION}

Nowadays, many types of different Photovoltaic (PV) modules are commercially available in the market. There are three (3) main types of PV module technology which are monocrystalline silicon, Heterojunction with Intrinsic Thin layer (HIT) and Thin-Film (TF). More efficient PV modules will lead to smaller PV array installations, generally comes from HIT and monocrystalline silicon with high power generation as well as the conversion efficiency varies from $12-24.2 \%$ (Green et al., 2017). On the other hand, PV module made from thin-film PV technology is low in manufacturing cost with high optical absorption coefficient. In addition, thin-film technology is non-toxic, robust and has higher system performance (Gan et al., 2013). However, the disadvantage of thin-film PV technology is instability in initial higher output that need several considerations in system design (Kumari and Babu 2012) as well as the efficiency of thin-film PV module typically lies in range from 5-12\% (Krautmann and Zhu 2012).

Research studies published by Akhmad et al. (1997) indicated that thin-film PV modules are more suited if installed in the tropical regions. This finding is also supported by Amin et al. (2009) which shows that thin-film and CIS solar cells has higher performance ratio as compared to c-Si solar cell under Malaysia climate condition. Mostly, thin-film PV technology has worked better in a hotter temperature due to smaller power temperature coefficient whereas c-Si PV technology responds more efficiently in average lower temperature under cold climate.

The results of the performance analysis such as capacity, yield and performance factors of a $1.4 \mathrm{~kW}$ roof top grid-connected photovoltaic power system under desert weather conditions in Sohar, Oman have been presented by Kazem et al. (2014). The system was monitored from July 2012-June 2013 and results show that the performance ratio and the annual energy production for the observed system are $84.6 \%$ and $2625.18 \mathrm{kWh}$, respectively.

In another study, analysis of yields and optimization potentials of 170 grid connected PV plants in Northern Germany is presented by Decker and Jahn (1997). The system has a total peak power $5 \mathrm{MWp}$. The annual final yields range between $430 \mathrm{kWh} / \mathrm{kWp}$ and $875 \mathrm{kWh} / \mathrm{kWp}$ with a mean value of $680 \mathrm{kWh} / \mathrm{kWp}$. The annual performance ratios are in range $47.5-81 \%$ (mean $66.5 \%$ ).

Corresponding Author: Chin Kim Gan, Faculty of Electrical Engineering, Universiti Teknikal Malaysia Melaka, Hang Tuah Jaya, 76100 Durian Tunggal, Melaka, Malaysia 
A summary of a 1 year of monitoring of a roof-mounted $1 \mathrm{kWp}$ grid-connected system in Warsaw, Poland is presented by Pietruszko and Gradzki (2003). The researchers have reported that the annual system energy yield was about $830 \mathrm{kWh}$ and the performance ratio ranged from $0.6-0.8$.

This study has evaluated the system performance of 3 grid-connected solar photovoltaic systems with different PV module technologies, namely, thin-film, HIT and monocrystalline for the period of 2 years. The total installed capacity is approximately $18 \mathrm{kWp}$ under the equatorial rainforest humid climate. The measured parameters are: output energy from the inverter, module temperature, ambient temperature and solar irradiance. The performance parameters including; Reference yield, final yield, array yield, performance ratio, system losses, array capture losses andcapacity factor of monocrystalline, HIT and thin-film PV systems are presented in this study due to lack of study and experience related to performance.

\section{MATERIALS AND METHODS}

PV systems description: The PV systems under evaluation are located at latitude $2.3^{\circ} \mathrm{N}$, longitude $102.3^{\circ} \mathrm{E}$ and with an altitude of $70 \mathrm{~m}$ above sea level. All of the 3 PV systems were installed on the roof top of admin and laboratory building at the Faculty of Electrical Engineering in UTeM, Malaysia. Naturally, the characteristic features of the climate of Malaysia are uniform temperature, high relative humidity and heavy rainfall throughout the year. The installation places of PV modules are shown in Fig. 1. Figure 2 is presented a schematic block circuit diagram of the PV systems. The modules were fixed and tilted at an angle of $10^{\circ}$. Each PV system has 3 inverters type SMA $2000 \mathrm{HF}$. PV system is usually composed of the four main following components:

- PV modules

- Inverters

- DC and AC cabling

- Utility meter (a)

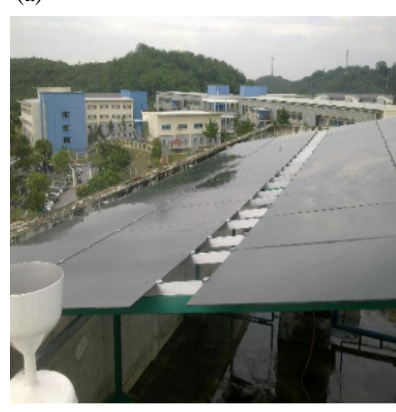

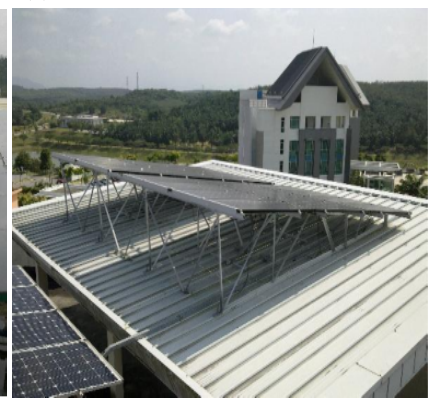

(c)

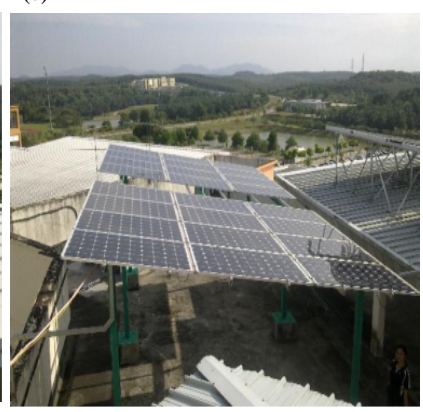

Fig. 1: Installation places of PV modules; a) Thin-film; b) HIT and c) Monocrystalline

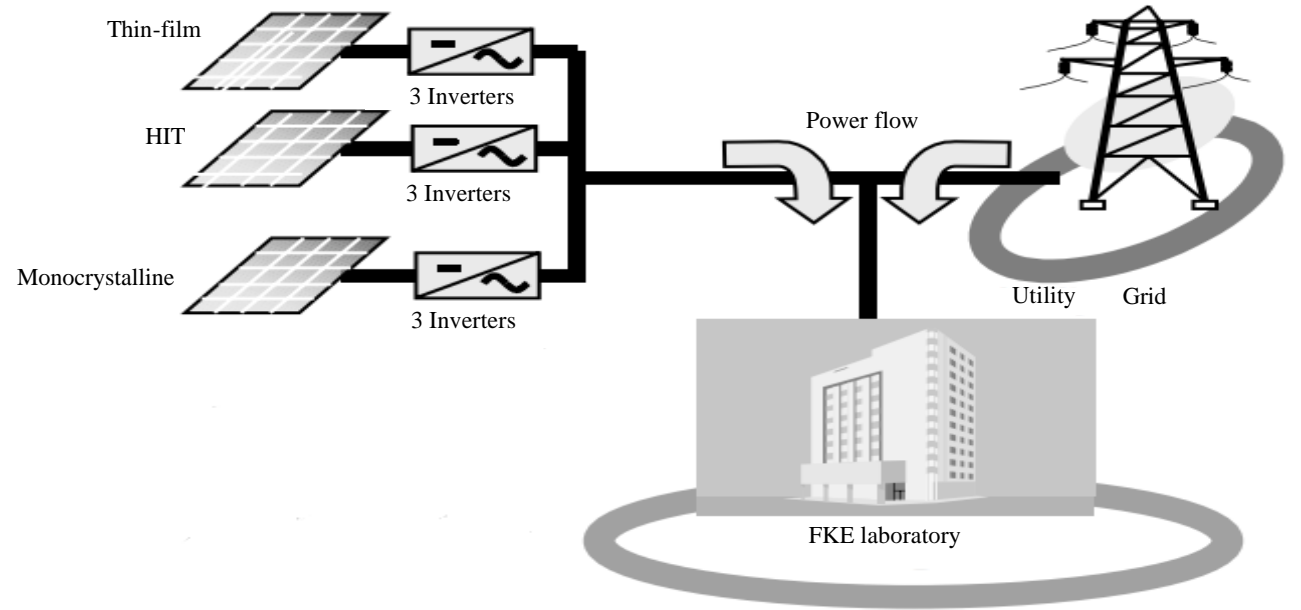

Fig. 2: Schematic block circuit diagram of the PV systems 
Table 1: Specifications of the thin-film, HT and monocrystalline PV arrays

\begin{tabular}{llll}
\hline & \multicolumn{2}{l}{ Specification } & \\
\cline { 2 - 4 } PV array & Thin-film & HIT & Monocrystalline \\
PV technology & $130 \mathrm{~W}$ & $235 \mathrm{~W}$ & $255 \mathrm{~W}$ \\
\hline Maximum Power $\left(\mathrm{P}_{\text {max }}\right)$ & $60.4 \mathrm{~V}$ & $51.8 \mathrm{~V}$ & $37.8 \mathrm{~V}$ \\
Open circuit Voltage $\left(\mathrm{V}_{\text {oc }}\right)$ & $3.41 \mathrm{~A}$ & $5.75 \mathrm{~A}$ & $8.66 \mathrm{~A}$ \\
Short circuit current $\left(\mathrm{I}_{\mathrm{s}}\right)$ & $46.1 \mathrm{~V}$ & $43.0 \mathrm{~V}$ & $31.4 \mathrm{~V}$ \\
Maximum power Voltage $\left(\mathrm{V}_{\text {mp }}\right)$ & $2.82 \mathrm{~A}$ & $5.48 \mathrm{~A}$ & $8.15 \mathrm{~A}$ \\
Maximum power current $\left(\mathrm{I}_{\text {mp }}\right)$ & $2.8 .3 \%$ & $18.6 \%$ & $15.51 \%$ \\
Module efficiency & 48 modules & 24 modules & 24 modules \\
Array module number & $6.24 \mathrm{kWp}$ & $5.64 \mathrm{kWp}$ & $6.12 \mathrm{kWp}$ \\
Nominal array power & \multicolumn{4}{l}{} \\
\hline
\end{tabular}

Table 2: Specifications of the SMA $2000 \mathrm{HF}$ inverter

\begin{tabular}{ll} 
Inverter & Specification \\
Maximum DC power & $2100 \mathrm{~W}$ \\
Maximum DC voltage & $700 \mathrm{~V}$ \\
MPP-voltage range & $175-560 \mathrm{~V}$ \\
Nominal AC power & $2000 \mathrm{~W}$ \\
Maximum efficiency/Euro-eta & $96.3 / 95 \%$ \\
Operating temperature & $-25+60^{\circ} \mathrm{C}$ \\
\hline
\end{tabular}

The specifications of the PV modules and inverter are listed in Tables 1 and 2, respectively.

Grid-connected PV systems performance parameters: The performance of the $18 \mathrm{kWp}$ grid-connected PV systems is analyzed using the performance parameters developed by International Energy Commission (IEC61724) (BSIG., 1998). These performance parameters include: final Yield $\left(\mathrm{Y}_{\mathrm{f}}\right)$, reference $\mathrm{Yield}\left(\mathrm{Y}_{\mathrm{r}}\right)$, array Yield $\left(Y_{a}\right)$, Performance Ratio $\left(\mathrm{P}_{\mathrm{R}}\right)$, system Losses $\left(\mathrm{L}_{\mathrm{s}}\right)$, array capture Losses $\left(\mathrm{L}_{c}\right)$ and Capacity Factor $(\mathrm{CF})$.

Final Yield $\left(\mathrm{Y}_{\mathrm{f}}\right)$ : The final Yield $\left(\mathrm{Y}_{\mathrm{f}}\right)$ is defined as the ratio of annual net energy output of the entire PV system which is supplied by the PV array to the rated power of installed $\mathrm{PV}$ array. The final yield can be expressed in unit of $\mathrm{h}$ or (kWh/kWp) and defined as (Kymakis et al., 2009):

$$
\mathrm{Y}_{\mathrm{f}}=\frac{\mathrm{E}(\mathrm{AC})}{\mathrm{P}_{0}}
$$

Where:

$\mathrm{E}(\mathrm{AC})=$ Output $\mathrm{AC}$ Energy from the inverter $(\mathrm{kWh})$ $\mathrm{P}_{0} \quad=\quad \mathrm{PV}$ array power rating at $\mathrm{STC}(\mathrm{kWp})$

Reference Yield $\left(\mathbf{Y}_{\mathrm{r}}\right)$ : The reference Yield $\left(\mathrm{Y}_{\mathrm{r}}\right)$ is defined as the ratio of annual total in plane solar radiation to the reference irradiance $\left(\mathrm{GSTC}=1 \mathrm{~kW} / \mathrm{m}^{2}\right)$. The reference yield can be expressed in unit of $\mathrm{h}$ or $(\mathrm{kWh} / \mathrm{kWp})$ and defined as (Kymakis et al., 2009):

$$
\mathrm{Y}_{\mathrm{r}}=\frac{\mathrm{H}}{\mathrm{G}_{\mathrm{STC}}}
$$

where, $\mathrm{H}$; Total in-plane irradiation, $\mathrm{kWh} / \mathrm{m}^{2}$

Array Yield $\left(\mathrm{Y}_{\mathrm{a}}\right)$ : The array $\mathrm{Y}$ ield $\left(\mathrm{Y}_{\mathrm{a}}\right)$ is defined as the ratio of annual PV array energy output to the rated power of installed PV array. The array yield can be expressed in unit of $\mathrm{h}$ or $(\mathrm{kWh} / \mathrm{kWp})$ and defined as (Kymakis et al., 2009):

$$
\mathrm{Y}_{\mathrm{a}}=\frac{\mathrm{E}(\mathrm{DC})}{\mathrm{P}_{0}}
$$

where, E (DC); Output DC energy from the PV array, kWh

Performance Ratio (PR): It is a dimensionless quantity. It is the ratio of final yield to the reference yield. It gives information about the impact of overall system losses on the rated output. The losses include tilt angle losses, PV array losses, dust losses, module temperature losses, inverter losses, cable losses and shade losses. Weather conditions such as ambient temperature and solar radiation are also impacting factors (Edalati et al., 2015). The performance ratio can be calculated as follows (Kumar and Sudhakar 2015):

$$
\mathrm{PR}=\frac{\mathrm{Y}_{\mathrm{f}}}{\mathrm{Y}_{\mathrm{r}}} \times 100 \%
$$

System Losses ( $\mathbf{L}_{s}$ ): System loss is the difference between array yield and final yield. The system losses can be calculated as follows (Kymakis et al., 2009):

$$
\mathrm{L}_{\mathrm{s}}=\mathrm{Y}_{\mathrm{a}}-\mathrm{Y}_{\mathrm{f}}
$$

Array capture Losses $\left(\mathrm{L}_{\mathrm{c}}\right)$ : Array capture loss is the difference between reference yield and array yield. The array capture losses can be calculated as follows (Kymakis et al., 2009):

$$
L_{c}=Y_{r}-Y_{a}
$$

Capacity Factor (CF): It is a dimensionless quantity. It is defined as the ratio of annual net energy output to the system capacity. The capacity factor can be calculated as follows (Kymakis et al., 2009):

$$
\text { Capacity Factor }(\mathrm{CF})=\frac{\text { Net energy output }}{\text { System capacity }} \times 100 \%
$$

where, System capacity $=$ PV system rated power $(\mathrm{kWp}) \times 24 \mathrm{~h} /$ day 365 day/year

\section{RESULTS AND DISCUSSION}

In this study, the data recorded during the period from 1st January 2014-31th December 2015 has been used for the performance analysis of the PV systems. A pyranometer and temperature sensors constitute the monitoring equipment of the grid-connected PV system, 


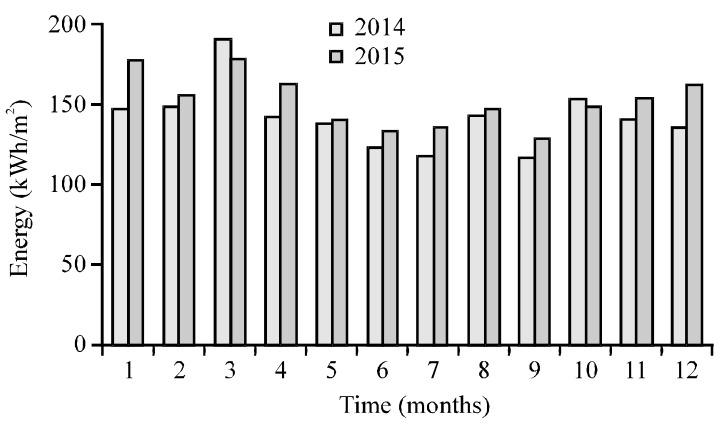

Fig. 3: Monthly average energy incident on tilted surface plane for 2 years at the PV systems site

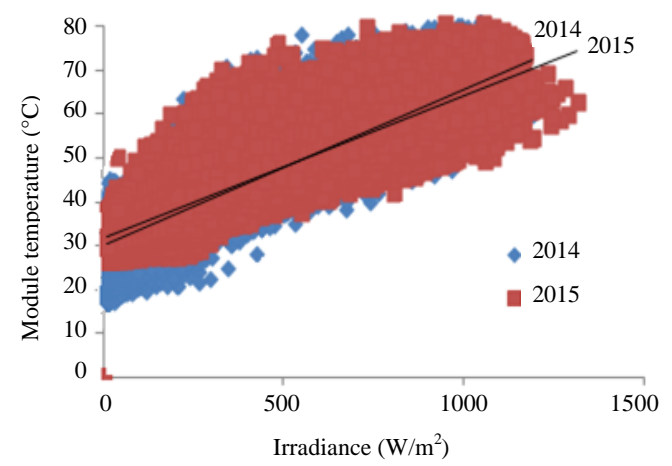

Fig. 4: Yearly rise in module temperature with respect to irradiance for 2 operational years of monocrystalline module

data of the meteorological parameters including solar radiation and ambient temperature and PV module temperature are recorded on $5 \mathrm{~min}$ intervals. The monthly average values of the energy incident on tilted surface plane for 2 years at the PV systems site are shown in Fig. 3, showing that the highest average irradiance exists in March (2014) and (2014). The average annual energy values received by the solar PV panels are $1842 \mathrm{kWh} / \mathrm{m}^{2}$ (2015) and $1792 \mathrm{kWh} / \mathrm{m}^{2}$ (2014).

The yearly rise in module temperature with respect to irradiance for 2 operational years of monocrystalline module is shown in Fig. 4 while Fig. 5 shows the yearly rise in module temperature with respect to irradiance for 2 operational years of thin-film module, indicating that the module temperature in (2014) is higher than the module temperature in (2015) for both 2 types of PV modules. The module temperature of thin-film is lower than the module temperature of monocrystalline at high irradiance levels and this can be attributed to the lower power temperature coefficient of thin-film module.

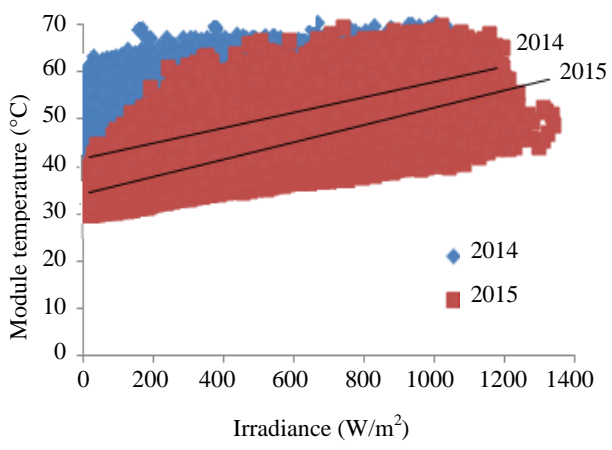

Fig. 5: Yearly rise in module temperature with respect to irradiance for 2 operational years of thin-film module

Table 3 shows the monthly average ambient temperature at the PV systems site (2014) while Table 4 shows the monthly average ambient temperature at the PV systems site (2015). The average ambient temperature varies through the year, ranging from $21.3-35.7^{\circ} \mathrm{C}(2015)$ and from $20.9-36.5^{\circ} \mathrm{C}(2014)$.

Table 5 shows the net energy output, capacity factor and performance ratio of thin-film, HIT and monocrystalline PV systems for 2 operational years, indicating that the thin-film PV system produced the highest energy output and this impacted well on the capacity factor $18.05 \%$ (2014) and $18.02 \%$ (2015) which translate into high efficiency of the thin-film PV system and also that the thin-film PV system has the highest performance ratio and this can be attributed to the low produce of losses of this system. In addition, this proves the thin-film PV system is in good working condition except for the high system losses produced in tropical regions.

Figure 6 shows the performance ratios drop of thin-film, HIT and monocrystalline PV systems across time, indicating that the monocrystalline PV system shows the lowest drop. Figure 7 shows the capacity factors drop of thin-film, HIT and monocrystalline PV systems across time, indicating that the thin-film PV system shows the lowest drop compared to HIT and monocrystalline PV systems.

Table 6 shows the calculated system losses of the 3 inverters of thin-film, HIT and monocrystalline PV systems for 2 operational years, indicating that the thin-film PV system produced lowest losses compared to HIT and monocrystalline PV systems. This is due to the high performance of thin-film PV system components. 
Table 3: Monthly average ambient temperature at the PV systems site (2014)

\begin{tabular}{|c|c|c|c|c|c|c|c|c|c|c|c|c|}
\hline Month & Jan. & Feb. & Mar. & Apr. & May. & Jun. & Jul. & Aug. & Sep. & Oct. & Nov. & Dec. \\
\hline Average temp $\left({ }^{\circ} \mathrm{C}\right)$ & 21.9 & 26 & 27.6 & 27.4 & 27.7 & 28.4 & 27.6 & 26.7 & 27 & 27.4 & 27.4 & 6.3 \\
\hline
\end{tabular}

Table 4: Monthly average ambient temperature at the PV systems site (2015)

\begin{tabular}{|c|c|c|c|c|c|c|c|c|c|c|c|c|}
\hline Month & Jan. & Feb. & Mar. & Apr. & May. & Jun. & Jul. & Aug. & Sep. & Oct. & Nov. & Dec. \\
\hline Average temp $\left({ }^{\circ} \mathrm{C}\right)$ & 26.3 & 26.8 & 27.8 & 27.7 & 27.9 & 27.9 & 27.6 & 27.3 & 27.1 & 27.2 & 26.8 & 27.1 \\
\hline
\end{tabular}

Table 5: Net energy output, capacity factor and performance ratio of thin-film, HIT and monocrystalline PV systems for 2 operational years

\begin{tabular}{|c|c|c|c|c|c|c|}
\hline \multirow[b]{2}{*}{ Variables } & \multicolumn{2}{|c|}{ Thin-film (Years) } & \multicolumn{2}{|c|}{ HTT (Years) } & \multicolumn{2}{|c|}{ Monocry stalline (Years) } \\
\hline & 2014 & 2015 & 2014 & 2015 & 2014 & 2015 \\
\hline Net energy output (kWh) & 9870.16 & 9852.15 & 8596.38 & 8553.68 & 8914.93 & 8867.79 \\
\hline Capacity factor & $18.05 \%$ & $18.02 \%$ & $17.39 \%$ & $17.31 \%$ & $16.62 \%$ & $16.54 \%$ \\
\hline Average performance ratio & $93.6 \%$ & $89.2 \%$ & $85 \%$ & $82.3 \%$ & $81.3 \%$ & $78.7 \%$ \\
\hline
\end{tabular}

Table 6: System losses of the 3 inverters of thin-film, HIT and monocrystalline PV systems for 2 operational years

\begin{tabular}{|c|c|c|c|c|c|c|}
\hline \multirow[b]{2}{*}{ Variables } & \multicolumn{2}{|c|}{ Thin-film (Years) } & \multicolumn{2}{|c|}{ HTT (Years) } & \multicolumn{2}{|c|}{ Mono crystalline (Years) } \\
\hline & 2014 & 2015 & 2014 & 2015 & 2014 & 2015 \\
\hline Inverter $1(\mathrm{kWh} / \mathrm{kWp})$ & 115.36 & 195.80 & 263.37 & 320.73 & 280.66 & 330.10 \\
\hline Inverter $2(\mathrm{kWh} / \mathrm{kWp})$ & 111.66 & 196.51 & 262.11 & 320.79 & 269.42 & 329.17 \\
\hline Inverter $3(\mathrm{kWh} / \mathrm{kWp})$ & 111.37 & 196.07 & 263.23 & 320.83 & 273.38 & 330.17 \\
\hline
\end{tabular}

Table 7: Array capture losses of the 3 inverters of thin-film, HT and monocrystalline PV systems for 2 operational years

\begin{tabular}{|c|c|c|c|c|c|c|}
\hline \multirow[b]{2}{*}{ Variables } & \multicolumn{2}{|c|}{ Thin-film (Years) } & \multicolumn{2}{|c|}{ HIT (Years) } & \multicolumn{2}{|c|}{ Monocrystalline (Years) } \\
\hline & 2014 & 2015 & 2014 & 2015 & 2014 & 2015 \\
\hline 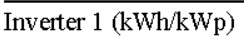 & -6.23 & -6.51 & 4.88 & 5.01 & 59.11 & 60.53 \\
\hline Inverter $2(\mathrm{kWh} / \mathrm{kWp})$ & -6.21 & -6.51 & 4.87 & 5.01 & 58.73 & 60.50 \\
\hline Inverter $3(\mathrm{kWh} / \mathrm{kWp})$ & -6.21 & -6.51 & 4.88 & 5.01 & 58.86 & 60.53 \\
\hline
\end{tabular}

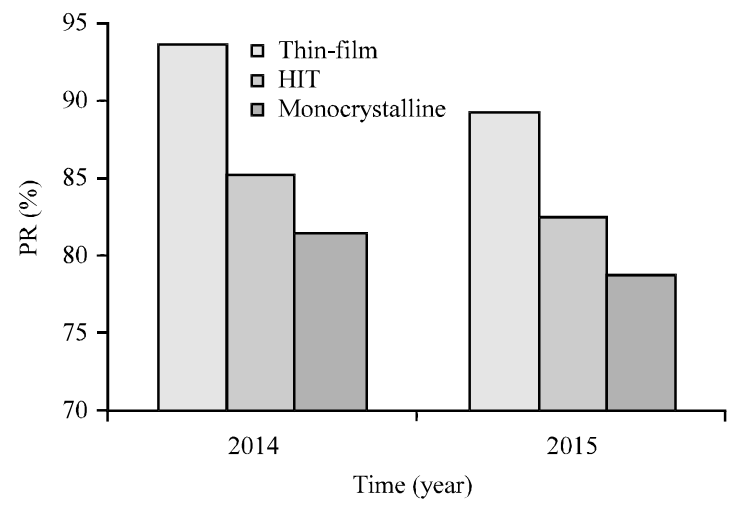

Fig. 6: Performance ratios drop of thin-film, HIT and monocrystalline PV systems across time

Results of calculating array capture losses of the 3 inverters of thin-film, HIT and monocrystalline PV systems for 2 operational years are shown in Table 7, indicating that the thin-film PV system produced lowest losses compared to HIT and monocrystalline PV systems. For thin-film PV system, the array capture loss is negative. This is most likely a result of low operating cell temperature of thin-film system and no soiling losses from snow or frost.



Fig. 7: Capacity factors drop of thin-film, HIT and monocrystalline PV systems across time

\section{CONCLUSION}

In this study, the $18 \mathrm{kWp}$ grid-connected photovoltaic systems installed at the Universiti Teknikal Malaysia Melaka (UTeM) was studied from January 2014-December 2015 and its performance parameters were determined on yearly basis as a conclusion the following results are obtained: 
- The annual average values of electricity generated by thin-film, HIT and monocrystalline PV systems were: $9861.15,8575$ and $8891.36 \mathrm{kWh}$, respectively

- The annual average final yields of thin-film, HIT and monocrystalline PV systems were: $1579.5,1520$ and $1452 \mathrm{kWh} / \mathrm{kWp}$, respectively

- The annual average performance ratios of thin-film, $\mathrm{HIT}$ and monocrystalline PV systems were: 91.48 , 83.68 and $80 \%$, respectively

- The annual average capacity factors of thin-film, HIT and monocrystalline PV systems were: $18 \%, 17.35 \%$ and $16.58 \%$, respectively

- The annual average system losses of thin-film, HПT and monocrystalline PV systems were: 154.46, 291.84 and $302.15 \mathrm{kWh} / \mathrm{kWp}$, respectively

- The annual average array capture losses of thin-film, HIT and monocrystalline PV systems were: $-6.36,4.94$ and $59.71 \mathrm{kWh} / \mathrm{kWp}$, respectively

- The electricity generated by PV systems can be used to power, air conditioning, lighting and other electrical appliances of the state building

\section{ACKNOWLEDGEMENTS}

The researchers gratefully acknowledge the research funding provided by the Ministry of Education Malaysia (Higher Education) under RAGS/1/2015/TK01/FKE/ 02/B00092. Hayder Salah Mohammad would like to thank UTeM Zamalah Scheme for.

\section{REFERENCES}

Akhmad, K., A. Kitamura, F. Yamamoto, H. Okamoto, H. Takakura and Y. Hamakawa, 1997. Outdoor performance of amorphous silicon and polycrystalline silicon PV modules. Solar Energy Mater. Solar Cells, 46: 209-218.

Amin, N., C.W. Lung and K. Sopian, 2009. A practical field study of various solar cells on their performance in Malaysia. Renewable Energy, 34: 1939-1946.

BSIG., 1998. Photovoltaic system performance monitoring: Guidelines for measurement, data exchange and analysis. BSI Group, London, England, UK.
Decker, B. and U. Jahn, 1997. Performance of 170 grid connected PV plants in Northern Germany: Analysis of yields and optimization potentials. Sol. Energy, 59: 127-133.

Edalati, S., M. Ameri and M. Iranmanesh, 2015. Comparative performance investigation of mono-and poly-crystalline silicon photovoltaic modules for use in grid-connected photovoltaic systems in dry climates. Appl. Energy, 160: 255-265.

Gan, C.K., P.H. Tan and S. Khalid, 2013. System performance comparison between crystalline and thin-film technologies under different installation conditions. Proceedings of the IEEE Conference on Clean Energy and Technology (CEAT), November 18-20, 2013, IEEE, Lankgkawi, Malaysia, ISBN: 978-1-4799-3238-2, pp: 362-367.

Green, M.A., K. Emery, Y. Hishikawa, W. Warta and E.D. Dunlop, 2017. Solar cell efficiency tables (Version 49). Prog. Photovoltaics Res. Appl., 25: 3-13.

Kazem, H.A., T. Khatib, K. Sopian and W. Elmenreich, 2014. Performance and feasibility assessment of a 1.4 $\mathrm{kW}$ roof top grid-connected photovoltaic power system under desertic weather conditions. Energy Build., 82: 123-129.

Krautmann, J. and J. Zhu, 2012. Photovoltaic solar energy systems: Market trends in the United States. Intl. J. Appl. Power Eng., 1: 123-128.

Kumar, B.S. and K. Sudhakar, 2015. Performance evaluation of $10 \mathrm{MW}$ grid connected solar photovoltaic power plant in India. Energy Rep., 1: 184-192.

Kumari, J.S. and C.S. Babu, 2012. Mathematical modeling and simulation of photovoltaic cell using Matlab-Simulink environment. Int. J. Electr. Comput. Eng., 2: 26-34.

Kymakis, E., S. Kalykakis and T.M. Papazoglou, 2009. Performance analysis of a grid connected photovoltaic park on the island of Crete. Energy Convers. Manage., 50: 433-438.

Pietruszko, S.M. and M. Gradzki, 2003. Performance of a grid connected small PV system in Poland. Appl. Energy, 74: 177-184. 